\title{
DETERMINATION OF THE INTENSITY OF RESPIRATION OF SMALL-SEEDED LEGUMES - THE KEY TO THEIR SAFE STORAGE
}

\author{
${ }^{1}$ Liudmyla Ovsyannikova, Candidate of Technical Sciences, Associate Professor \\ ${ }^{1}$ Liudmyla Valevskaya, Candidate of Technical Sciences, Associate Professor \\ ${ }^{1}$ Olena Sokolovskaya, Candidate of Technical Sciences \\ ${ }^{1}$ Viktoria Urkovskaya, graduate student \\ ${ }^{2}$ Svitlana Orlova, Candidate of Technical Sciences, Associate Professor
}

${ }^{1}$ Department of grain storage technology

Odessa National Academy of Food Technologies

${ }^{2}$ Department of electrical mechanics and mechatronics

Odessa National Academy of Food Technologies

DOI: https://doi.org/10.31435/rsglobal_ws/30082018/6049

\section{ARTICLE INFO}

Received: 20 July 2018

Accepted: 15 August 2018

Published: 30 August 2018

\section{KEYWORDS}

legumes,

lentils,

mash,

intensity of breathing,

natural losses.

\begin{abstract}
The article presents important factors for the storage of small-fruited legume crops. The intensity of respiration is an indicator of the biological activity of stored cereal masses. We determined the intensity of respiration of lentils and masha and its dependence on grain moisture was determined. Also, the calculation of natural losses of lentils and masha at various values of grain moisture and their deviation from the norm of natural loss was carried out.
\end{abstract}

Citation: Liudmyla Ovsyannikova, Liudmyla Valevskaya, Olena Sokolovskaya, Viktoria Urkovskaya, Svitlana Orlova. (2018) Determination of the Intensity of Respiration of Small-Seeded Legumes - The Key to Their Safe Storage World Science. 8(36), Vol.1. doi: 10.31435/rsglobal_ws/30082018/6049

Copyright: (C) 2018 Liudmyla Ovsyannikova, Liudmyla Valevskaya, Olena Sokolovskaya, Viktoria Urkovskaya, Svitlana Orlova. This is an open-access article distributed under the terms of the Creative Commons Attribution License (CC BY). The use, distribution or reproduction in other forums is permitted, provided the original author(s) or licensor are credited and that the original publication in this journal is cited, in accordance with accepted academic practice. No use, distribution or reproduction is permitted which does not comply with these terms.

Introduction. To date, there is no wonder the variety of legumes on the trade counters. A significant place among them is occupied by various species and varieties of lentils and masha. Due to their unique chemical composition, these cultures are widely used throughout the world in various branches of the food industry and are a universal component of health nutrition.

We have been working on the definition of physical, physico-technological, hygroscopic, consumer and other properties of these crops, which definitely determine the modes and methods for their processing and storage. It should be noted that grain storage is one of the most important stages, which determines the quality of raw materials during processing and the quality of the seeds during sowing. It can produce as a positive effect, contributing to the improvement of quality as a result of post-harvest achievement, and negative, resulting, under the influence of various factors, to a decrease in quality [1-5].

It should be noted that at all stages of the harvest from harvesting to consumption, there are significant losses of its mass and quality. After harvesting during transportation and storage, 5-25\% of grain is lost due to the technical equipment of the elevators and the general culture of the storage organization [6].

The nature of the losses of grain products in the mass is well studied. They are divided into mechanical and biological. 
Only some types of grain losses can not be avoided, others occur due to improper storage and can not be justified. Thus, the inevitable mechanical loss is unaccounted spraying, which occurs during the movement of grain masses and products. Loss of dry matter due to the breath of grain during storage is recognized as the only justifiable loss of biological order.

Breathing is an important physiological process that is the basis of metabolism in living organisms. During breathing, there is a process of distillation of the reserve organic substances, mainly of sugars, which results in the release of energy necessary to maintain the vital reactions of the organism. Only a small part of the energy of breathing of the grain is used for its needs, most of its (90 ... 95\%) is released in the form of heat, causing an increase in the temperature of the grain mass, deterioration of its preservation [6, 7].

For the life of each organism, a constant supply of energy is required. It appears as a result of the cleavage and transformation of substances in it, that is, in the process of dissimilation. This energy promotes the synthesis of substances in the body, necessary for its livelihoods, the formation, growth and development of new cells and tissues. Energy is released as a result of the distillation of organic matter, mainly of sugars. The spent sugar is replenished in the body as a result of hydrolysis or oxidation of more complex spare substances. So, in grains rich in starch, it splits with the participation of enzymes to sugars [7-9].

Distillation of sugars (hexose) in the body occurs aerobically, ie oxidation, or anaerobic fermentation. From the point of view of organizing storage of grain masses, it is important to know what kind of dismilliation prevails during storage, how the process of dismilliation affects the quality and condition of the cereal masses and which factors influence the intensity of the disiligration. In the process of storing grain and seeds, there are both types of distillation.

Aerobic process of distillation - aerobic breathing, when there is a complete oxidation of hexose with the formation of the source products of photosynthesis - carbon dioxide and water.

Under anaerobic decomposition, undoxified products - ethyl alcohol and carbon dioxide - are formed.

Anaerobic breathing always accompanies aerobic. With enough access to air in grains and seeds, the aerobic breathing process prevails. But they also have anaerobic respiration, which is sometimes seen as adapting to adverse environmental conditions [6-9].

As a result of the distillation of organic matter in the grain mass, the following significant changes are made:

- weight loss of dry substances;

- increase of the quantity of hygroscopic moisture in grain, increase of relative humidity of air between the grains;

- change in the air composition of the environment in the intergranular spaces;

- the formation of heat in the grain mass.

Loss of dry substances during storage is an irreversible process. However, their value depends on the intensity of breathing, and therefore the study of factors affecting the process is of great practical importance.

Water released during respiration is often retained by grain, increasing the moisture content of the latter. This, in turn, leads to more intense gas exchange and creates preconditions for the development of microorganisms. The saturation of moist air in the intergranular spaces increases to a certain extent. It causes the formation of condensate on the surface of objects, ie, their fogging. This phenomenon is most characteristic of freshly harvested grain mass. As a result of product breathing carbon dioxide is released. When stored grains without moving, it is delayed in the intergranular spaces. Such a phenomenon is observed in the inner surfaces of large mounds, in silos.

The effect of carbon dioxide depends on the moisture content of the grain. In dry grain, with an extremely low level of breathing, its effect is not negative. Conversely, in a wet grain, conditions are created which make the cells of the grains go over to anaerobic type of respiration. Anaerobic respiration products, in particular, ethyl alcohol, suppress the vital functions of the cells of the grains and lead to loss of vitality. The release of energy in the process of breathing causes the accumulation of heat in the mass due to poor heat conductivity. If this heat is not forced out to the environment, there is a self-heating of products [6,7].

The purpose of the work was to determine the intensity of respiration of small-seeded legumes (lentils and masha), depending on the humidity.

Determination of the intensity of respiration was carried out by the weight method, which is based on the quantitative accounting of $\mathrm{CO} 2$ released by the grain mass during storage. The method of breathing is based on the capture of a solution of caustic barium of carbon dioxide, which grants the grain when breathing. The intensity of the breath of the grain is expressed in terms of the number of milligrams of carbon dioxide isolated by $100 \mathrm{~g}$ of dry matter of grain in 24 hours [10, 11]. 
We studied the intensity of respiration of such small-seeded legume crops as lentil and mash in the range of changes in their humidity $\mathrm{w}=13.7 \ldots 18.4 \%$.

Research results. At the first stage of work, the intensity of respiration of the studied cultures at various moisture values was determined. The moisture content of the grain is chosen in a way that corresponds to different grain conditions in humidity (dry, medium dry and moist). The results of the research are shown in the table. 1

Table 1. Intensity of respiration of small-seeded legumes, mg CO2 per $100 \mathrm{~g}$ of dry matter.

\begin{tabular}{|c|c|c|c|c|c|c|}
\hline \multirow{2}{*}{ Culture } & \multicolumn{2}{|c|}{ Dry grain } & \multicolumn{2}{c|}{ Grain of medium dryness } & \multicolumn{2}{c|}{ Damp Grain } \\
\cline { 2 - 7 } & humidity & $\begin{array}{c}\text { the intensity } \\
\text { of breathing }\end{array}$ & humidity & $\begin{array}{c}\text { the intensity } \\
\text { of breathing }\end{array}$ & humidity & $\begin{array}{c}\text { the intensity } \\
\text { of breathing }\end{array}$ \\
\hline Mash & 13,7 & 7,5 & 16,2 & 22,4 & 18,4 & 44,4 \\
\hline $\begin{array}{c}* \text { Lentil } \\
\text { variety A }\end{array}$ & 14,4 & 13,8 & 16,0 & 25,4 & 18,2 & 47,5 \\
\hline $\begin{array}{c}* * \text { Lentil } \\
\text { variety B }\end{array}$ & 14,2 & 11 & 16,2 & 22,3 & 18,0 & 42,2 \\
\hline
\end{tabular}

Note: * Lentil variety A - fennel lentil (breeding line);

** Lentil variety B - flaxseed lentils (varietal Maxim).

Graphic dependence of the intensity of respiration of small-legume legumes on the moisture $\mathrm{w}$ is shown in Fig.1.

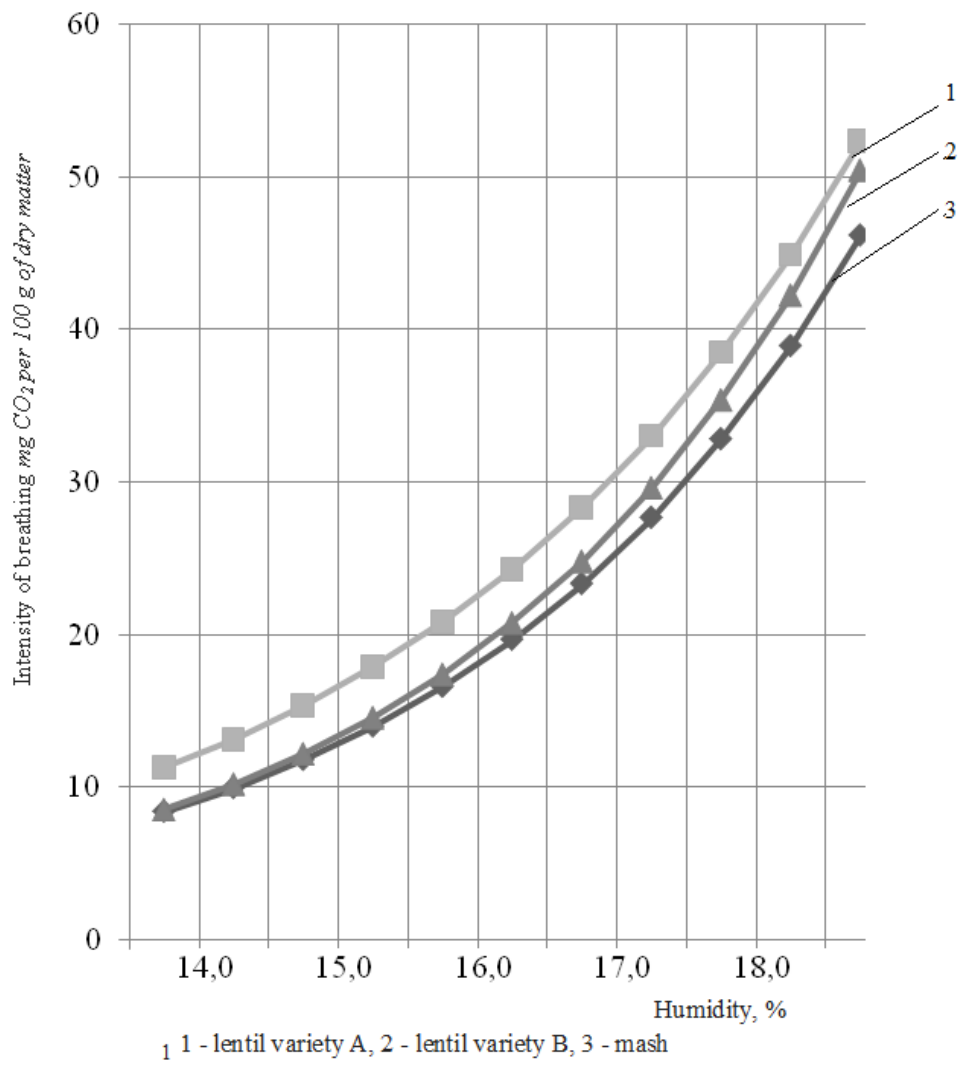

Fig. 1 Dependence of the intensity of respiration of small-seeded legumes on moisture

Humidity of grain mass - the most important and reliable factor of regulation of its vital activity. Grain moisture is an environment in which all life processes take place. The first portions of moisture absorbed by dry grain, amplify its breath to a small extent. When the grain reaches a certain level of humidity, the intensity of breathing increases sharply. Humidity of the grain, from which the physiological-biochemical and microbiological processes sharply increase and storage conditions change, is called critical. Consequently, the critical moisture content of the grain corresponds to its level, above which it appears free moisture, sharply increases the intensity of respiration and there is a threat of damage to microorganisms. 
It has been established that with increasing grain humidity, the intensity of respiration increases. With an increase in humidity of $13.7 \ldots 18.4 \%$, the intensity of crops increases in 3.4 ... 5.9 times.

At the next stage of the work, the natural loss of grain at respiration as a percentage was determined for a completely dry substance for the studied crops (Table 2).

When stored as a result of the consumption of substances on the respiration there is a decline in the mass of the grain (natural decline), self-heating of the grain, the influence on it of molds, eating insects, rodents, birds. Only natural losses are justified, the rest of the factors need to be eliminated.

Table 2. Natural losses of small-seeded legumes during storage

\begin{tabular}{|c|c|c|}
\hline Culture & Humidity, \% & Natural loss, \% \\
\hline \multirow{3}{*}{ Маш } & 13,7 & 0,045 \\
\cline { 2 - 3 } & 16,2 & 0,137 \\
\cline { 2 - 3 } & 18,4 & 0,271 \\
\hline \multirow{2}{*}{ Lentil variety A } & 14,4 & 0,008 \\
\cline { 2 - 3 } & 16,0 & 0,185 \\
\cline { 2 - 3 } & 18,2 & 0,355 \\
\hline \multirow{2}{*}{ Lentil variety B } & 14,2 & 0,006 \\
\cline { 2 - 3 } & 22,3 & 0,162 \\
\cline { 2 - 3 } & 42,2 & 0,315 \\
\hline
\end{tabular}

Losses during storage should not exceed the established norms of natural loss of grain. For legumes, the norm of natural grain loss is $0.045 \%$ for three months of storage.

The analysis of the data obtained allows us to conclude that increasing the moisture content of the grain leads to an increase in its natural losses. Only with minimum humidity (13.7 ... 14.4\%) the natural losses of lentils and masush do not exceed the established norms.

Knowing the causes of grain loss allows you to timely decide on its processing and thereby reduce them. The experiments confirmed that the grain moisture has an effect on grain stability during storage. The timely reduction in the moisture content of the grain mass is one of the important methods of lowering the intensity of breathing, which is widely used in storage.

Conclusions. The essential condition for storing grain mass is the intensity of breathing, which must be reduced to the lowest possible level. The most important and most reliable factor in the regulation of grain life, used in the practice of storage, is its humidity

They determined the intensity of respiration of small-seeded legumes, its dependence on the moisture content of the grain was determined, so when the grain moisture content is higher than the critical, there is a rapid increase in the intensity of respiration.

The calculations made by the natural losses of mash and lentils during storage show that when grain moisture increases, their natural losses are significantly increased. Natural losses of small-seeded legume crops stored in dry condition do not exceed the norm of natural losses of grain during storage.

\section{REFERENCES}

1. Орехівський В. Д., Січкар В. І., Овсянникова Л. К. Сочевиця джерело рослинного білка. Зернові продукти і комбікорми. 2017; 4: 22-29.

2. Овсянникова Л. К., Валевська Л. О., Орлова С. С. Харчова цінність та споживні властивості дрібнонасіннєвих бобових культур. Web of Scholar. 2017; 1: 7-9.

3. Овсянникова Л. К., Валевская Л. А., Орлова С. С., Щербатюк С. И. Актуальные проблемы использования семян чечевицы. International Scientific and Practical Conference World Science. 2017; 11 (27): 4-6.

4. Овсянникова Л. К., Валевская Л. А., Орлова С. С., Щербатюк С. И. Полезные свойства семян чечевицы. Актуальные научные исследования в современном мире. 2017; 10: 47-49

5. Овсянникова Л. К., Валевська Л. О., Чумаченко Ю. Д., Соколовська О. Г. Харчова цінність та гігроскопічні властивості дрібнонасіннєвих бобових культур. Мат. 78 наукової конференції науково-педагогічного складу ОНАХТ. Одеса. 2018: 29-31.

6. Ящук Н. Втрати зерна: причини, наслідки та способи запобігти. Пропозиція. 2011; 7: 60-62.

7. Пузік Л. М. Технологія зберігання і переробки зерна. Навч. посіб. Харків: ХНАУ. 2013: 312.

8. Трисвятский Л. А. Хранение зерна. Учебник. Москва. Агропромиздат. 1986: 400 с.

9. Пилипюк В. Л. Технология хранения зерна и семян. Учеб. пособ. Москва: Вузовский учеб. 2009: 455.

10. Стародубцева А. И. Практикум по хранению зерна. Учеб. Пособ. Москва. Агропромиздат. 1987: 192.

11. Подпрятов Г. І., Скалецька Л. Ф., Сеньков А. М. Технологія зберігання і переробки продукції рослинництва. Практикум: навч. посіб. Киів.: Вища освіта. 2004: 272. 